NBER WORKING PAPER SERIES

\title{
ASSET PRICE INFLATION AND MONETARY POLICY
}

\author{
Anna J. Schwartz \\ Working Paper 9321 \\ http://www.nber.org/papers/w9320 \\ NATIONAL BUREAU OF ECONOMIC RESEARCH \\ 1050 Massachusetts Avenue \\ Cambridge, MA 02138
}

November 2002

William S. Vickrey Distinguished Address Prepared for the International Atlantic Economic Society Meeting in Washington, D.C., October 11, 2002. The views expressed herein are those of the authors and not necessarily those of the National Bureau of Economic Research.

(C) 2002 by Anna J. Schwartz. All rights reserved. Short sections of text, not to exceed two paragraphs, may be quoted without explicit permission provided that full credit, including $(\mathcal{C}$ notice, is given to the source. 
Asset Price Inflation and Monetary Policy

Anna J. Schwartz

NBER Working Paper No. 9321

November 2002

JEL No. E5, E6, G2, N1, N2

\section{$\underline{\text { ABSTRACT }}$}

It is crucial that central banks and regulatory authorities be aware of effects of asset price inflation on the stability of the financial system. Lending activity based on asset collateral during the boom is hazardous to the health of lenders when the boom collapses. One way that authorities can curb the distortion of lenders' portfolios during asset price booms is to have in place capital requirements that increase with the growth of credit extensions collateralized by assets whose prices have escalated. If financial institutions avoid this pitfall, their soundness will not be impaired when assets backing loans fall in value. Rather than trying to gauge the effects of asset prices on core inflation, central banks may be better advised to be alert to the weakening of financial balance sheets in the aftermath of a fall in value of asset collateral backing loans.

Anna J. Schwartz

National Bureau of Economic Research

365 Fifth Avenue, $5^{\text {th }}$ Floor

New York, N.Y. 10016-4309

aschwartz@gc.cuny.edu 


\section{ASSET PRICE INFLATION AND MONETARY POLICY}

\section{Introduction}

Several recent papers have addressed the question of whether central banks should respond to changes in asset prices. Bernanke and Gertler (1999) emphasized inflation-targeting as the primary responsibility of monetary authorities whom they enjoined to respond only if asset price changes signaled changes in expected inflation. On the other hand, Cecchetti, Genberg et al. (2000) urged the authorities to react to asset price inflation as much as to goods and services price inflation in formulating monetary policy decisions. Asset price inflation in their view was a predictor of core inflation.

In two follow-up papers these authors essentially repeat their initial positions. Cecchetti, Genberg, and Wadhwani (2002) respond to their critics and find no reason to alter their recommendation to monetary authorities. Likewise, Bernanke and Gertler (2001) reiterate their judgment that monetary authorities should not respond to asset price inflation.

For monetary authorities to be able to target inflation assumes that they can forecast it. A paper by Stock and Watson (2000) raises a question about their ability to do so. For G-7 countries these authors find no indicator that reliably predicts future rates of inflation, so casting doubt on the recommendation by Cecchetti et al. that reliable signals of inflation can be extracted from asset prices.

Asset price inflation, of course, can take many forms, raising prices of art objects, land, housing purchases, equities. Cecchetti, Genberg et al. conclude that housing inflation should be given a larger weight than equity prices in a measure of core inflation to which authorities should respond by adjusting the interest rate that they use as their instrument. Goodhart (2001) endorses this conclusion.

The foregoing papers restrict their consideration of asset price inflation to its relationship to achieving the target of inflation that most central banks currently regard as their mandate. 
Asset price inflation has other dimensions, however, that should not be neglected. It is relevant to ask whether monetary policy contributes to asset price inflation. It is also relevant to ask whether asset price inflation affects the portfolios of financial institutions in ways that spell trouble for them should the asset price inflation collapse. Monitoring financial institutions may be a responsibility of regulatory authorities rather than monetary authorities, but monetary policy decisions inevitably are influenced by a worsening condition of financial institutions. An example occurred in some financial crises of the 1990s, when monetary authorities hesitated to institute contractionary policies that they otherwise would have adopted. They feared that higher interest rates would prove catastrophic for already weakened banks and therefore refrained from raising them.

Monetary authorities need to be alert to policies they pursue that may promote asset price inflation. Even if they cannot be tagged with responsibility for asset price inflation, when it occurs, they should be alert to changes in portfolios of financial institutions that asset price inflation induces. In the past, as we shall see below, they have taken steps to end the asset price boom, since that was the source of the change in portfolios. An alternative response to deal with the problem would be to control the portfolio effects without directly confronting asset prices if monetary policy is free of involvement. In that event, restraint on the portfolio effects might serve indirectly to dampen or even obviate the asset price boom. If there are no portfolio effects, whether an asset price boom should be a concern of the authorities becomes a debatable question.

The motive for focusing on portfolio effects is not to rescue financial institution investors from the consequences of management's shortsighted risk-laden lending decisions. What is of concern is that taxpayer funds should not be used to bail out these institutions when their balance sheets reveal that liabilities exceed assets. If the financial institution is a bank, funds of the deposit insurance agency may be drawn upon in a rescue. The temper of the times is such 
that failure is regarded as politically unacceptable, so taking action that precludes a failure is held to be warranted. The ultimate effect of forbearance, however, may inflict larger costs than when a timely response by supervisors prevents institutional weakness.

There may be fewer pitfalls for the authorities in trying to determine whether asset price inflation is damaging from paying attention to changes in the composition of financial institutions' portfolios than from trying to gauge the effects of asset prices on core inflation. Assuming that monetary policy has not generated the bubble, a response by the authorities to limit the weakening of financial balance sheets as a result of asset price inflation may be a more effective solution with less collateral damage to the economy than the solution of raising interest rates to puncture a bubble. Preventing a deterioration in the quality of financial institution balance sheets has the further advantage that the need does not arise, in the aftermath of a fall in value of asset collateral backing loans, to clean up portfolios. Even if financial institutions emerged unscathed in the aftermath of an asset price boom, they might still be undermined should the authorities pursue flawed policies, as happened after 1930.

This paper investigates the condition of financial institutions when asset prices are escalating and when asset prices crash. It examines the role of monetary policy, if any, in accounting for the upswing in asset prices as well as for the downswing. Monetary policy may have had no responsibility for the upswing and yet be implicated in the unwinding of the succeeding asset price debacle.

I propose to examine the behavior of monetary and regulatory authorities with respect to the performance of financial institutions, first, during two major episodes of a sustained rise in equity prices in the twentieth century (section 2) -- 1926-29 in the United States and 1985-89 in Japan -and, second, during the subsequent sustained fall in equity prices (section 3) - 1929-33 in the United States and 1989-02 in Japan. Asset prices other than those of equities also were involved during some of these episodes, and their effects on financial institutions are examined. 
In section 4, I review the spectacular annual growth in U.S. equity prices in 1995-2000 to check for financial institution involvement, and note the subsequent decline in asset prices. Section 5 concludes.

I begin with some history to learn how financial institutions fared during the upswing and then the downswing in equity prices and the reaction if any of the authorities.

\section{Equity Price Inflation}

For each episode, I review (a) the extent of the rise in asset prices; (b) the accompanying change in portfolios of financial institutions; (c) the response of authorities; (d) alternatives to that response.

\subsection{The United States in the 1920s}

\subsubsection{The Upswing}

Prices of equities advanced through most of the months from the end of 1924 until the peak in September 1929, but the most spectacular gains occurred from 1926 on. The Dow-Jones industrial annual average in each of these years was $167,202,300$,with a peak of 381 in September 1929. The corresponding Standard \& Poor composite 500 stock price averages were $12.59,15.34,19.95$, with a peak of 31.30 in September 1929.

Whether these price increases were justified by prospective earnings growth is still in dispute. White (1990, p. 78) believes that qualitative evidence suggests "the existence of conditions that enhanced the likelihood of a bubble," although econometric tests for a speculative bubble are inconclusive. The equity upsurge was not matched by commodity prices, which showed no tendency to rise. Wholesale prices on a 1926 base fell to 95.3 in 1929.

\subsubsection{Financial Institution Portfolios}

What is indisputable is the nature of Federal Reserve Board concern that the stock market advances aroused. Banks extended loans to investors that their security purchases collateralized. No better description is available of the Federal Reserve's revulsion with such a practice than the 
following extract (Willis and Chapman 1934, p. 621): “The banks liked the security loan

because it seemed like a conveniently 'liquid' and therefore safe asset. They did not realize that in the 1927-1929 period they were thus directly aiding and abetting the common-stock boom and infecting the whole structure, that the securities were only liquid as long as speculators were willing and able to support the market for them at dizzy heights; that the enormous issues of new securities amounting to fifty billions in five years, and stock prices of 200 times earnings represented a national gambling mania; and that in thus furthering and directly stimulating industrial fluctuations and distorting the price structure, they were conducting themselves in a manner directly contrary to rudimentary banking principles."

The reference to banking principles was to the real bills doctrine, which distinguishes between "productive" and "speculative" use of credit. Credit restricted to productive uses financed additions to output, hence was non-inflationary. Credit to finance acquisition of common stocks was speculative and, since it did not increase output, was inflationary.

The absence of commodity price inflation while speculative use of credit was growing did not disturb belief in the real bills doctrine. Monetary authorities as well as regulators and examiners of banks were well informed about the change in bank portfolios as a result of the increase in loans on securities. $^{1}$

\footnotetext{
${ }^{1}$ Weekly reporting members of the Federal Reserve System in leading cities from December 1919 on provided Wednesday figures on their loans and investments (Banking and Monetary Statistics 1943, pp. 133-42). Before 1929, total loans distinguished loans on securities from all other loans. Beginning 1929 the category of loans on securities was further classified into loans extended to brokers and dealers (those in New York City shown separately from those outside New York City) and loans to others than brokers and dealers. The authorities also had quarterly reports on brokers' loans by New York City banks, by other banks, and by others (ibid., p. 494). Another data set shows loans to brokers and dealers made by daily reporting banks in New York City, for their own account and for correspondents, weekly, from October 1917 through January 1926( ibid., pp. 496-97). Thereafter weekly data for loans to brokers and dealers, secured by stocks and bonds, are available for weekly reporting member banks in New York City (ibid., pp. 498-99).
}

Brokers used their loans to provide the call loan market. Investors who bought equities on margin borrowed the difference from a broker who had a daily option to call the loan, which paid a floating interest rate. Dealers borrowed pending the distribution of shares to investors.

Loans to brokers and dealers by member banks were a particular bane of the Board. As member banks reduced such loans on their own account, they made loans for the account of correspondent out-of-town banks and 
In June 1920 loans on securities were $32 \%$ of the loan portfolio of weekly reporting member banks in 101 leading cities. By June 1926, the figure was 40\%, and by June 1929, 44\%. Loans to brokers and dealers, despite the attention the Board lavished on them, constituted only $29 \%$ of loans on securities in that month. White $(1990$, p. 74$)$ asks how credit to buy stocks could have been easy in 1928-29 when credit in general was tight because Federal Reserve policy was contractionary. In fact, interest rates on brokers' loans increased sharply, to levels much higher than the discount rate and commercial paper rate. It was not an increase in the aggregate supply of bank credit during the boom, but a reallocation in favor of loans on securities that supported rising stock prices.

Loans on securities indicated that the real bills doctrine was being violated. That view was more potent in exercising the Federal Reserve Board than disapproval of the equity market boom. As it stated in February 1929, "The Federal Reserve Board neither assumes the right nor has it any disposition to set itself up as an arbiter of security speculation or values" (Annual Report 1929, p. 3).

\subsubsection{Response of the Authorities}

In 1928 the Federal Reserve Board sought to curb speculative bank lending by restricting access to the discount window of the Federal Reserve Banks by banks that were liberal in extending loans on securities. The way the Board intended to achieve this end was that the Reserve Banks would apply direct pressure to offending banks by refusing to discount for them. The Board believed that direct pressure would succeed in reducing loans for speculative purposes without interfering with loans for productive purposes. It was unwilling to approve a rise in discount rates in order not to limit productive loans. The New York Reserve Bank as well as others

in 1929 increasingly for the account of nonbanking lenders -- private investors and corporations -- and foreign banks (ibid., p. 498).

(The banks did not report loans on real estate or types of loans other than loans on securities until September 1934) 
opposed the Board's policy and instead advocated rises in discount rates or open market sales to curb speculation. They believed the Reserve Banks had no legal right to refuse to rediscount for member banks that held eligible paper, that, only if an individual member bank borrowed for protracted periods or far in excess of amounts borrowed by others, should it be denied rediscounting facilities, and that correction of a member bank's portfolio was a matter of internal bank management, not the business of its Reserve Bank (F\&S 1963, p. 257).

The New York Reserve Bank directors repeatedly in 1929 voted to raise discount rates but not until August 1929 did the Federal Reserve Board approve. That month marked the cyclical peak. The following month the stock market crashed. It is ironic that neither outcome was the objective of the Federal Reserve. It did not intend to end the stock market boom and it did not seek to halt the business expansion.

\subsubsection{Alternatives to the Authorities Response}

Neither direct pressure nor discount rate rises dealt directly with the problem of bank portfolios with a growing proportion of collateralized loans at values set when equity prices were escalating. The position of the New York Reserve Bank was that it was a matter of internal bank management to correct a portfolio overloaded with equity collateral of uncertain future value . This condition could have been a concern of bank regulators and examiners not in order to spare the banks involved from the follies of their lending decisions, but to spare the economy from those consequences.

What measures could have been taken in advance to avoid a prospective crisis for the financial system after the asset boom collapsed? A deterrent to the distortion of bank portfolios would have been a capital requirement that increased with the growth of the proportion of collateralized loans. Authorities would have been required to monitor compliance by banks. If the banks were able to raise capital along with the growth of asset-backed loans as a proportion of their portfolios, they would not have been vulnerable when the value of the collateral they 
held dissipated. Had such a scheme been in place, the representation of collateral on bank balance sheets might not have grown to levels that became a problem when asset price inflation peaked, and the peak itself might have been lower.

\subsection{Japan in the 1980s}

\subsubsection{The Upswing}

Equity prices tripled and land prices doubled in the dramatic rise in asset prices in Japan in the second half of the 1980s. The Nikkei 225 stock price index rose from 13,000 in December 1985 to 26,000 in October 1987, when it declined briefly but then recovered to almost 39,000 at the end of 1989. Land prices in Japan rose at an annual rate of 13\% between 1985 and mid-1990, rising more in than outside major cities, and commercial land increasing in value faster than residential land, with industrial land lagging both. Consumer price inflation remained relatively low. The general consumer price index rose from 87.4 in 1985 to 88.0 in 1987, to 90.7 in 1989 .

Was the surge in asset prices a bubble? One analyst assigns a role also to fundamentals (Kähkönen 1995): 25\% growth of real GDP; 69\% growth of corporate profits. However, easy monetary policy and declines in interest rates to historically low levels, and liberalization of financial markets as well as distortions of Japan's land tax system indicate a bubble.

\subsubsection{Financial Institution Portfolios}

To determine the extent of the exposure of the financial system to equity price inflation, for the U.S. case it is enough to check how much the loan portfolio of institutions shifted in favor of loans backed by equity collateral. For the Japanese case, that information must be supplemented with data on holdings of equity by financial institutions, a balance sheet asset denied U.S. banks.

The Bank of Japan collects data on both asset entries: corporate equities as well as loans outstanding of domestically licensed banks by kind of collateral (Economic Statistics Annual 1997, pp. 210, 55). Domestically licensed banks include city banks, regional banks, regional banks II, trust banks, long-term credit banks, and other financial institutions. Some of the types 
of banks may not have been included in reports of early years of the asset price boom, so the numbers referred to here may distort the true shift in the equity holdings and the loan portfolios of domestically licensed banks. Although I confine discussion of asset price inflation to banks, Japanese life insurance companies were also significant purchasers of equities and hence vulnerable to sharp falls in their prices.

The value of equities held by domestically licensed banks more than doubled between 1985 and 1989, but there has been no downturn in this account since then until 1997, when holdings were 17 percent higher than in 1989. However, as a percent of total assets, equities were negligible, 3 percent in 1985, 4 percent in 1989, 6 percent in 1997 . Nevertheless, as shown in what follows, holdings of corporate equity by the banks have been lethal to their soundness in the aftermath of the asset price boom. . If the valuation of equities were marked to market, the banks' capital would have been seriously impaired.

The two categories that reflect the impact of asset price inflation are loans secured by real estate and floating mortgages and loans secured by stocks and bonds. Major changes in these two categories occurred between the end of fiscal year 1985 and 1989, but loans secured by real estate and floating mortgages far surpassed loans secured by stocks and bonds. The former were 11 times the size of the latter in 1985 and not quite 10 times the size of the latter in 1989. Real estate collateral loans, however, did not peak until 1992, two years after real estate prices crashed, whereas the security collateral loans peaked in 1989. Both categories increased at about the same pace, despite the difference in their levels, security collateral loans in $19892 \frac{3}{4}$ times higher than in 1985, real estate collateral loans in 1992 nearly 3 times higher than in 1985 . While security collateral loans constituted only 1 or 2 percent of total bank assets, real estate collateral loans accounted for 14 percent of total bank assets in 1985, 18 percent in 1989, and 20 percent in 1992. 
Banks and nonbank lenders increased lending to the real estate sector in part to replace lending to large manufacturing corporations that were able to access international capital markets once controls on capital markets were dismantled after 1979. Deregulation of interest rates on deposits led banks to lend to small firms backed by property. Despite the increased risk of loan portfolios, easy monetary conditions in the second half of the 1980s kept interest rates from rising enough to compensate for the higher risk. Households also found credit easily available, deployed it in the stock market, and drove up equity prices.

\subsubsection{Response of the Authorities}

Japanese authorities resorted to moral suasion during the period of asset price inflation to restrain bank lending while maintaining monetary ease. From January 1986 to February 1987, the Bank of Japan lowered the discount rate five times, reaching a low of $2.5 \%$. The second to the fifth discount rate declines were instituted in response to pressure from the industrialized countries for Japan to support international policy coordination in order to boost Japanese domestic demand and to contain yen appreciation. The discount rate was unchanged from February 1987 to May 1989. From the second quarter of 1987 the Bank began to urge commercial banks to be prudent lenders, with little effect. On 1 April 1989 a consumption tax was introduced and on 31 May 1989 the discount rate was raised to $3.25 \%$. The Bank called on commercial banks to improve the quantity and quality of their lending. On four subsequent dates the discount rate was raised, reaching $6 \%$ on 30 August 1990 .

\subsubsection{Alternatives to the Authorities Response}

Inflated land prices became the backing for an egregious expansion of bank credit, which continued past the second half of the 1980s. Bank authorities could foresee severe effects on the soundness of Japanese bank portfolios once land prices declined. Because of their limited share of total assets, equities that served as collateral for loans presaged less damaging effects of inflated corporate equity prices than property collateral on the quality of bank portfolios. A more 
serious issue that was not adequately weighed during the equity price boom was the role of equity that banks owned by taking stakes in the corporations with which they formed business relationships. A plunge in share prices would impose valuation losses that could breach minimum capital requirements.

What action could the authorities have taken to restrain bank lending to the real estate sector?

Given the policies that produced the asset boom - the liberalization of the tightly regulated financial system in the first half of the 1980s, and the easy monetary policy of the second half of the $1980 \mathrm{~s}$ - there is a counterfactual that could have deflected the boom's consequences for financial institutions.

Japan could have had in place capital requirements that increased as the ratio of each loan category (real estate loans, loans secured by stocks and bonds, unsecured loans, etc.) to the total loan portfolio rose and the ratio of each category of assets other than loans (equities, bonds, etc.) to total assets rose of each subclass of banks. ${ }^{2}$ The responsibility of the bank supervisory agency would have been to monitor changes in the ratios quarter by quarter and to ascertain that the institutions held adequate capital.

Banks would have had to sell assets to reduce the ratio when it exceeded the matching capital requirement. They would then have been allowed to continue to operate. Banks that ignored the rule would have been sanctioned. Had such a system been in place, the boom might have been restrained. Japan's financial institutions would have been spared the baleful consequences to their portfolios that still plague them since the bursting of the bubble. Instead of raising interest rates to deter bank lending, the authorities could have relied on rising capital requirements to control changes in the composition of financial institution portfolios.

\footnotetext{
${ }^{2}$ I owe comments by George Kaufman on an earlier version of this paper for the present reliance on capital requirements as the solution to the problem of portfolio distortions during asset price inflations.
} 
Another obvious counterfactual would have been conduct by the Bank of Japan of a stable monetary policy instead of the lax policy that was a precondition for the asset boom.

Finally, the unforeseen consequences of bank ownership of corporate equities could have been averted only by a change in legislation governing banks and insurance companies. Restriction or prohibition of the right of financial institutions to hold equities would have been desirable.

\subsection{The United States 1929-33}

\subsubsection{The Downswing}

From the September 1929 peak of 381 the Dow Jones Industrial Index declined to 199 in November, recovered to 294 in April 1930, fell to a low of 158 in December 1930, recovered to 194 in February 1931, fell to 74 in December 1931, recovered to 89 in March 1932, fell to 41 in

July 1931, and at the business cycle trough in March 1933 was $55{ }^{3}$ The annual averages of the S \& P 500 composite index fell from 21 in 1930 to 14 in 1931 to 7 in 1932 and stood at 6 in March 1933.

The profound collapse of the economy was mirrored in declines in stock prices, output, national income, consumer prices, short-term interest rates, and the money stock. Bank failures reached historic proportions culminating in a nationwide bank holiday.

\subsubsection{Financial Institution Portfolios}

It was enough to show the rising proportion of loans backed by securities to highlight the distortion of bank portfolios that asset price inflation produced. It is not enough to report that proportion, which in fact did not change much after 1929, during the ensuing asset price collapse. The true measure of the banks' financial distress once asset price deflation set in was the plunge of the market values of their assets to levels far below book values: not only loans backed by securities but also loans for real estate, commodities, and general business as well as

\footnotetext{
${ }^{3}$ Wigmore 1985, App. 19, pp. 637-39,
} 
their holdings of corporate and foreign bonds. The root explanation of this result was Federal Reserve failure to respond to the distress.

\subsubsection{Response of the Authorities}

The Federal Reserve took no responsibility for the failure of banks, member and nonmember banks alike. A new institution, the Reconstruction Finance Corporation, was created in January 1932 with authority to lend $\$ 1.5$ billion to railroads and banks. It made loans that were publicized for political reasons. Unfortunately, that publicity harmed the banks that borrowed. Moreover, the banks that were salvageable needed infusions of capital more than loans. The RFC lacked authority to do so until the Emergency Banking Act of March 9, 1933, empowered it to invest in the preferred stock or capital notes of commercial banks. There is no comparable example of the devastating portfolio effects the U.S. banking system experienced from 1930 to 1933.

\subsubsection{Alternatives to the Authorities Response}

Monetary expansion by the Federal Reserve in 1930 and 1931 could have shielded the banks from runs that contracted their reserves and reduced the money supply. Asset prices would not have plunged to the extent that they did, bankrupting industrial corporations, public utilities and railroads. Jobs and consumer purchases would not have suffered the enormous declines they experienced. Depression in the rest of the world would not have been so pronounced. By 1932, when the Fed undertook a $\$ 1$ billion open market purchase, the program was curtailed prematurely, reversing the upturn in prices and production that it had succeeded in achieving. The banks and the economy tailspinned into their final collapse.

\subsection{Japan in the 1990s}

\subsubsection{The Downswing}

The Nikkei 225 stock price index began to decline in February 1990 from a high of 39,000, falling below 14,000 in August 1992.By mid-May 1993 the index reached 21,000, but fell back 
to 16,000 in November 1993. Pump-priming government public works expenditure announcements have led to increases in stock prices, followed by declines as recession has resumed. Stock prices recorded a bottom of 9072 in September 2002. Subsequently the index fell below 9000.

Land prices ceased to rise in mid-1990. At the end of 1993, land prices in the six largest cities were 36 percent below their 1990 peak. Land prices in 1999 were $20 \%$ lower than in September 1985 and 80\% lower than in September 1990 (Okina et al. 2000, p. 3). As of mid2002 land prices had not stabilized.

Cyclical chronology dates the period February 1991 to October 1993 as a recession, when durable goods output and residential and business fixed investment declined along with a rapid decline in the growth rate of monetary aggregates. A second period of low growth occurred in 1995 when commodity prices fell and the exchange value of the yen appreciated, despite a declining stock market. In both instances the government increased public works spending to stimulate recovery. In 1997 financial institution failures and an increase in the consumption tax triggered a resumption of recession. A redefinition of GDP growth by the government increased what was originally reported as negative growth in 1997 and 1998 to positive $0.1 \%$ annual growth. In 1999 the government spent $\$ 70$ million to recapitalize 15 major banks and relaxed fiscal policy. Improvement in the economy that seemed to follow petered out in 2000.

The Japanese economy contracted in each quarter of 2001, but apparently did not decline further in the first quarter of 2002. It emerged from recession in the second quarter, thanks to export-driven growth. The appreciation of the yen in early 2002 led the finance ministry to engage in seven rounds of yen-selling intervention for fear that the exchange rate would abort the recovery. 
Reliance on budget deficits throughout the post-1990 period that have raised the public debt to $\$ 4.6$ trillion, well over $100 \%$ of GDP, induced Moody's to downgrade government bonds two notches to A2, much to Japan's shock.

\subsubsection{Financial Institution Portfolios}

Twelve years after the asset market boom in Japan collapsed financial institutions, both depository and non-depository ones alike, are trying to recover from its aftereffects. Major banks and insurance companies have failed - two banks in 1998, four life insurance companies in 2000, and a regional bank in 2001 -- but many more are believed to be insolvent. In Japan in 2002 the survivors still bear the scars that asset deflation has inflicted on their portfolios. Each industry has its share of bad debts from loans that went sour when land prices collapsed in the early 1990s, and suffered erosion of its capital base.

The problem for these institutions is that the companies that borrowed from them are delinquent, surviving only because the banks do not foreclose on their loans. The banks in turn have no incentive to lend, given the load of non-performing loans in their portfolios, so bank support for economic activity is anemic. The government has not made a firm decision to compel insolvent companies to file for bankruptcy protection, although periodically it announces reform programs that halfheartedly tackle the problem but do not resolve it. Likewise, the government has been ambivalent about the measures to employ to deal with insolvent financial institutions

Direct write-offs from fiscal 1992 to end of March 1999 amounted to 53.9 trillion yen at major banks, about $11 \%$ of nominal GDP, but still more non-performing loans were thereafter recorded on the books of banks. There is no end in sight of write-offs of non-performing loans, officially estimated in 2002 as totaling 52.4 trillion yen (\$4.28 trillion). Private estimates are much higher.

In April 2001 banks were required to mark their investment portfolio to market effective a year later. Limits were also imposed on equity ownership. Japan's nine biggest banks have 
equity investments that are larger than their core capital and for years have been selling shares in an effort to improve their financial health. A falling equity market in 2002 saddled them with significant capital shortfalls. Unlimited insurance of deposits in Japanese banks, originally scheduled to end in March 2003, may not eventuate. Observers believe that, if the change occurs, it will endanger the existence of some banks and smaller financial institutions.

\subsubsection{Response of the Authorities}

Until December 2001, the two principal anti-recession actions by the authorities in the 1990s were, first, cutting short-term interest rates successively to virtually zero percent, and, second, implementing successive fiscal stimulus measures, as noted above. Japan's government debt currently is the largest of major industrial countries (114\% of GDP, whereas $60 \%$ is the comparable U.S. figure). As of 2002, the policy responses had not succeeded in generating selfsustained recovery of private demand.

A belated attempt to deal with non-performing loans was the establishment of the Resolution and Collection Corporation in March 1998 to buy such loans from failed and healthy financial institutions. It is authorized to buy assets only at prevailing market prices, and is not allowed to lose money on its resales. (It turned a profit in 2001, but has had a net loss since its start. It transfers profits to the Deposit Insurance Corporation, its parent.) The banks have urged the agency to buy loans at book value, using taxpayer funds, but the agency's regulator has so far not acquiesced. The problem of non-performing loans remains unresolved.

The principal development in December 2001 was the Bank of Japan's announcement that it would expand the monetary base and add some financial instruments to the list of those that it customarily buys. As of mid-2002, reserve growth has expanded without much effect on broader aggregates and credit availability.

No concerted policy was directed to the problems of undercapitalized institutions, where the choices were either to shut down those beyond salvage or to inject public funds into the rest. 
Instead, piecemeal measures were introduced. In June 1996685 billion yen of public funds was applied to the liquidation of failed bank-affiliated non-banks and jusen companies with nonperforming loans. 1.8 trillion yen in public funds was injected into 21 major banks. In October 1998 funds appropriated for financial system stabilization were increased to 60 trillion yen, and in 1999 the government bought 7.5 trillion yen of 15 big banks preferred shares and 2.6 billion yen to shore up the capital of four regional banks. The financial services minister said any necessary capital injections would be made on a case by case basis. As of 2002, the health of Japanese banks is still in question, more than a decade since their perilous condition has been known.

Part of the delay in cleaning up banks' bad debts and determining which insolvent banks should be closed is attributable to the government's policy of shoring up the banks' weakest borrowers. Although some firm bankruptcies have risen, again much more needs to be done.

Neither of the twin weaknesses of the banks - non-performing loans and overvalued equity holdings - has been corrected. A government-sponsored fund to buy shares from banks has not made much progress.

In a surprising move in September 2002 the Bank of Japan announced that it would buy at market prices corporate equity directly from the biggest banks with equity holdings in excess of Tier 1 capital. The seven largest ones own 25.8 trillion yen (\$200 billion) worth of shares. The Bank proposes to buy $\$ 24$ billion shares, the purchases to continue for up to two years. (By September 2004 equity holdings of banks must be reduced to the amount of Tier 1 capital). The Bank of Japan will hold the shares it purchases for up to ten years. It said that it would not announce the names of the banks from which it would buy. The Bank's intention apparently is to send a signal to the government that it was time for it to undertake real reform..

It is not clear how monetary policy will be affected by the purchase of equities by the Bank. Will it sterilize its purchases?. How much its balance sheet will be damaged by the 
acquisition of shares of uncertain quality remains to be seen. The Bank proposes to establish a reserve fund to cover potential losses.

.The Bank's initiative disturbed the Japanese bond market, which undersubscribed the government's debt auction on 18 September.The world is still in doubt whether Japan will finally eliminate bad debts from bank portfolios, restore their capital to appropriate levels, and succeed in either shutting down bankrupt borrowers or restructuring them. It is a great unknown.

\subsubsection{Alternatives to the Authorities Response}

The industry whose problems could have had the highest priority among the concerns of authorities was that of financial institutions. Instead of fixating on the foreign exchange value of the yen, and manipulating fiscal policy, they could have been focusing on the condition of banks and insurance companies.

The balance sheets of financial institutions were loaded with non-performing loans. Mori et al. (2000) defend forbearance on this problem by bank regulators when the bubble first burst, since they hoped for early recovery of the economy and the real estate market, but they argue that it was not forbearance later on that explains the regulators' behavior. Rather they waited until there was an adequate safety net before tackling writing-off non-performing loans. The result was a frozen credit supply by troubled financial institutions and distrust of the institutions by the public throughout the decade.

The government lavished public funds on public works construction to revive the economy to no avail. Public funds would have been better spent to restore the financial industry to sound condition.

Since the bursting of the bubble, the monetary authorities have relied on a virtual zero interest rate policy rather than on expanding the annual growth rate of monetary aggregates to promote monetary ease. Belatedly, the Bank of Japan responded in December 2001, as noted above, to the recommendation of many observers, to aggressively expand the monetary base. Its 
announcement in September 2002 that it would purchase excess corporate shares in bank portfolios is another belated effort to counter bank capital problems and ultimately lead them to deal with their bad loans.

Perhaps monetary and financial policy reforms will finally enable Japan to emerge from its prolonged economic stagnation.

\section{U.S. Equity Prices, 1995-2002, and Monetary Policy}

Since 1995 the U.S. stock market has had its biggest boom ever. The Dow Jones rose annually from 3834 at year-end 1994, to 5117, 6448, 7908, 9181, and 11,145 in 1999. The comparable end-of December figures for the Standard \& Poor index are 460, 542, 670, 873, 1086, 1327, and for the Nasdaq 752, 1052, 1291, 1570, 2193, 4069.

As in other episodes, it is hard to determine the extent that fundamentals - the usual ones cited are low unemployment, low inflation, rapid productivity growth - account for equity price escalation, and the extent that herd behavior by investors has caused equity prices to overshoot their "fair" values. A more important fundamental has been the increase in corporate efficiency and profitability that the takeover movement a decade earlier generated in the 1990s.

Since the start of 2000, when market highs were reached: the Dow Jones (11723 on 14/1), the Standard \& Poor 500 (1527), and the Nasdaq (4963 on 24/3), the stock market has retreated, most sharply by the Nasdaq. Rallies have been short-lived. Equity prices fell sharply after the 9/11/2001 terrorist attacks on the World Trade Center buildings, recovered somewhat in the months thereafter but fell again most drastically beginning in April 2002 as revelations of corporate accounting malfeasance shocked investor confidence. Stock market valuations by July were at lower levels than in October 1997. The Dow registered 7702, the S\&P 797, and the Nasdaq 1229. In early August the Nasdaq fell even lower to 1206, and in September to 1172. The Dow also fell further in September to 7591, and in early October to 7528. Corporate 
malfeasance combined with the threat of war with Iraq have been more destructive to market valuations than the twin tower attack.

One question is whether the Federal Reserve has had any responsibility for stock market prices either during the upswing or the downswing as far as it has gone as of the summer of 2002. Two statements by Fed Chairman Greenspan may be cited. On 5 December 1996 he referred to "irrational exuberance" in describing the behavior of stock market investors, and the Dow Jones declined 2.3\%. The warning was not repeated, so the Fed's position since has in essence been agnostic about what the level of stock market prices should be.

Four years later to the day, Greenspan in a speech to New York bankers hinted that the Fed might lower the fed funds rate sometime soon and the Nasdaq rose that day by $10.47 \%$, the other indexes by about 3\%, all giving up most of their gains on the following day. The objective of the chairman's speech was surely not to add to volatility of market performance. On 24 September 2002, when the market anticipated that the Fed would cut the Fed funds rate but it did not do so, the Dow and the Nasdaq fell to new lows. It is hard to fault the Fed for the market's belief that monetary policy should be guided by the price of equities.

Chairman Greenspan in a speech on 30 August 2002 at the Kansas City Fed Symposium in Jackson Hole, Wyoming, remarked that incremental policy tightening seemed incapable of deflating a bubble, and that he did not know of other options that could limit the size of bubbles without doing substantial damage in the process. I agree.

Some observers believe that monetary policy, judged from an acceleration of M2 and M3 growth rates in 1998, has been accommodative, facilitating the upswing (Fand 1999). That was certainly true of the 75 basis points fed funds rate reduction in 1998. Not until November 1999 did the Fed fully withdraw that easing. It then raised rates a further one percent over the next half-year ending May 2000. There is no metric by which to gauge whether these monetary actions by the Fed played a role that favored either rising equity prices before March 2000 or 
highly volatile equity prices thereafter. In any event, all equity prices were not uniformly affected. On balance one may conclude that the Fed has been a bystander rather than actively promoting or inhibiting the market's rise and recent fall. Had the Fed been more restrictive --how much more is an unknown --with the aim of moderating the market's rise, what would the tradeoff have been? Lower economic growth, a business expansion of shorter duration?

From the perspective of this paper, what is of central interest is the effect on banks and other financial institutions of the asset price boom. In the six years since June 1994, total bank credit at all commercial banks has grown approximately 1.5 times. Components of that total that responded to the asset boom - real estate bank credit, bank credit backed by securities other than government securities, and security loans - increased at a somewhat more rapid rate than the total, 1 2/3 times, 2.3 times, and 2 times, respectively. Banks, however, are well capitalized, so their condition is not at this juncture fragile.

It is too early in the post-asset boom period to determine whether bank portfolios with such collateral will spell trouble for those lenders. Security collateral may be problematic to dispose of, presumably subject to a big loss. Banks will foreclose on property that is backing for troubled loans and then sell it. The real estate market has not as of the summer of 2002 suffered a retreat, so the banks may not be losers if the borrowers have trouble servicing their loans.

Some banks have already reported weaker earnings, and a surge in bad loans. It has been alleged that some of the nation's largest banks facilitated corporate concealment of losses and debts. Bank stocks since May 2002 have been battered by these allegations. Enron-related activities by big banks are being investigated by various agencies. How damaging to the financial system the outcome will be remains to be seen.

Money-center banks are in a different position. They have invested in venture capital underwriting, and advising on mergers and acquisitions. They syndicate big loans to corporations, usually not backed by collateral, arranging for a fee for several other banks and 
investors to accept a portion of the loan. Big syndicated loans to the big corporate miscreants that have filed for bankruptcy may well inflict losses on the lenders. Defaults on subinvestment grade lending, however, have not been a serious problem as of the first half of 2002.

The economy faltered in 2000 and initially the slowdown seemed not to signal recession. However, revised GDP data for 2001 show that the economy contracted during the first three quarters. The decline was shallow.despite the shock of the 9/11 attacks. Before the release of the revised GDP estimates, the NBER dating committee designated March 2001 as the peak of the expansion dating from March 1991. GDP in the fourth quarter of 2001 rose $2.7 \%$ and $5 \%$ in the first quarter of 2002, falling to $1.3 \%$ in the second quarter. The economic recovery, weak as it appears to be, has continued despite the rout of equity prices 


\section{Conclusion}

This brief survey points to two negative admonitions for central banks. The first one is, Do not engage in monetary expansion out of concern for depressed asset prices. The second admonition is, Do not direct monetary policy to deflate asset price booms. Let the market correct itself when asset price booms appear to be bubbles. The Federal Reserve is not the arbiter of the correct level of asset prices.

Equity market prices don't escalate in the absence of favorable earnings growth projections; they don't collapse unless those earnings growth projections are diminished. There may be lots of noise surrounding these basics, but the noise should not obscure the underlying reality.

Recently Henry Kaufman (2002) has argued that plummeting stock prices are cause for concern because of their direct bearing on the real economy. He urges the Fed to support equity prices by reducing margin requirements on stocks, which he characterizes as an underutilized tool.

The direct effect of the stock market usually referred to is the wealth effect that was supposed to stimulate or retard consumer spending. The failure of consumer spending to respond to the stock market collapse in the years since 2000 has muted the belief in.the potency of the wealth effect. Kaufman, however, has in mind a different direct effect, namely, the general malaise associated with the shutdown of the IPO market, high borrowing costs for established businesses, restricted access to low-cost commercial paper issuance, the shrinking high-yield corporate bond market - threats to recovery, all of which he associates wth the depressed stock market. Reducing margin requirements hardly seems an effective cure for these problems.

Kaufman's second recommendation, however, is more to the point, but is unrelated to monetary policy. He believes that President Bush should propose and Congress enact a reduction in the capital gains tax and the elimination of the tax on corporate dividends. Only if these 
measures don't stabilize the stock market would Kaufman advocate a reduction of the Fed funds rate and across the board cut in taxes. I would agree that tax policy is the appropriate tool to improve the climate for investment.

Achieving a low commodity price inflation rate remains the paramount central bank responsibility. Should commodity price inflation emerge, before central banks attempt to divine whether it is attributable to asset price inflation, they would be well advised to make sure that lax use of their interest rate instrument is not at fault.

What is crucial, however, is that central banks and regulatory authorities, be aware of effects of asset price fluctuations on the stability of the financial system. Lending activity based on asset collateral during the boom is hazardous to the health of lenders when the boom collapses. One way that authorities can curb the distortion of lenders' portfolios during asset price booms is to use capital requirements that increase with credit extensions collateralized by assets whose prices have escalated. If financial institutions avoid this pitfall, their soundness will not be impaired when assets backing loans fall in value. If there are troubled financial institutions, following an asset price collapse, restoring them to sound condition ranks first among the authorities' urgent priorities. No economy can prosper without a well-functioning financial industry. 


\section{References}

Annual Report 1929. Federal Reserve Board. Washington D.C.

Banking and Monetary Statistics 1914-1941. 1943. Board of Governors of the Federal Reserve System.

Bernanke, Ben and Mark Gertler. 2001. "Should Central Banks Respond to Movements in Asset Prices?" American Economic Review (v. 91, May), pp. 253-257.

Cecchetti, Stephen G., Hans Genberg, John Lipsky, and Sushil Wadhwani. 2002. “Asset Prices in a Flexible Targeting Framework.” Chicago: Federal Reserve Bank of Chicago and the World Bank.

Cecchetti, Stephen G., Hans Genberg, John Lipsky, and Sushil Wadhwani. 2000. Asset Prices and Central Bank Policy. London: International Center for Monetary and Banking Studies.

Economic Statistics Annual 1997. Research and Statistics Department, Bank of Japan.

Fand, David I. 1999. “Are We Facing a Stock Market Bubble?” George Mason University mimeo. July.

Friedman, Milton and Anna J. Schwartz. 1963. A Monetary History of the United States 18671960. Princeton: Princeton University Press.

Gertler, Mark, and Ben Bernanke. 1999. "Monetary Policy and Asset Price Volatility," in New Challenges for Monetary Policy, a symposium sponsored by the Federal Reserve Bank of Kansas City, August 26-28.

Goodhart, Charles. 2001. "What Weight Should be Given to Asset Prices in the Measurement of Inflation?” Economic Journal (v.111, June), pp. F335-F356.

Kähkönen, Juha. 1995. "Movements in Asset Prices Since the Mid-1980s" in Ulrich Baumgartner and Guy Meredith eds. Savings Behavior and the Asset Price "Bubble" in Japan. Washington, D.C.: IMF. 
Kaufman. Henry. 2002. “A Double Dip Wouldn't Be A Summer Treat.” Wall Street Journal. August 7, p. A14.

Mori, Naruki, Shigenori Shiratsuka, and Hiroo Taguchi. 2000. "Policy Responses to Post-Bubble Adjustments in Japan: A Tentative Review,” Bank of Japan Institute for Monetary and Economic Studies Discussion Paper, May.

Okina, Kunio, Masaaki Shirakawa. And Shigenori Shiratsuka. 2000. "The Asset Price Bubble and Monetary Policy: Japan's Experience in the Late 1980s and the Lessons," Bank of Japan Institute for Monetary and Economic Studies Discussion Paper, May.

Stock, James, and Mark Watson. 2001. "Forecasting Output and Inflation: The Role of Asset Prices," (March). NBER Working Paper 8180.

White, Eugene N. 1990. “The Stock Market Boom and Crash of 1929 Revisited.” Journal of Economic Perspectives 4:2, 67-83.

Wigmore, Barrie A. 1985. The Crash and its Aftermath: A History of Securities Markets in the United States, 1929-1933. Westport, Connecticut: Greenwood Press.

Willis, H. Parker and John M. Chapman. 1934. The Banking Situation: American Post-War Problems and Developments. New York: Columbia University Press. 